\title{
Interaction between the trout mineralocorticoid and glucocorticoid receptors in vitro
}

\author{
Pia Kiilerich", Gérard Triqueneaux', Nynne Meyn Christensen², Vincent Trayer, \\ Xavier Terrien, Marc Lombès ${ }^{3}$ and Patrick Prunet
}

Correspondence should be addressed to P Kiilerich or P Prunet Emails pkiilerich@bio.ku.dk or prunet@rennes.inra.fr

\begin{abstract}
The salmonid corticosteroid receptors (CRs), glucocorticoid receptors 1 and 2 (GR1 and GR2) and the mineralocorticoid receptor (MR) share a high degree of homology with regard to structure, ligand- and DNA response element-binding, and cellular co-localization. Typically, these nuclear hormone receptors homodimerize to confer transcriptional activation of target genes, but a few studies using mammalian receptors suggest some degree of heterodimerization. We observed that the trout MR confers a several fold lower transcriptional activity compared to the trout GRs. This made us question the functional relevance of the MR when this receptor is located in the same cells as the GRs and activated by cortisol. A series of co-transfection experiments using different glucocorticoid response elements (GREs) containing promoter-reporter constructs were carried out to investigate any possible interaction between the piscine CRs. Co-transfection of the GRs with the MR significantly reduced the total transcriptional activity even at low MR levels, suggesting interaction between these receptors. Co-transfection of GR1 or GR2 with the MR did not affect the subcellular localization of the GRs, and the MR-mediated inhibition seemed to be independent of specific activation or inhibition of the MR. Site-directed mutagenesis of the DNA-binding domain and dimerization interface of the MR showed that the inhibition was dependent on DNA binding but not necessarily on dimerization ability. Thus, we suggest that the interaction between MR and the GRs may regulate the cortisol response in cell types where the receptors co-localize and propose a dominant-negative role for the MR in cortisolmediated transcriptional activity.
\end{abstract}

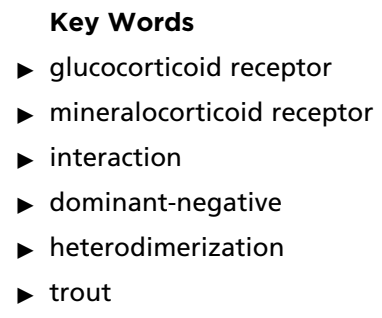

Journal of Molecular Endocrinology (2015) 55, 55-68

\section{Introduction}

The glucocorticoid and mineralocorticoid receptors (GR and $\mathrm{MR}$ ) belong to a superfamily of ligand-activated transcription factors, the NR3C steroid receptor subgroup.
The cytoplasmic steroid receptors are activated upon ligand binding and translocate to the nucleus, where they recognize specific palindromic DNA sequences and http://jme.endocrinology-journals.org DOI: 10.1530/JME-15-0002
(C) 2015 Society for Endocrinology Printed in Great Britain
Published by Bioscientifica Ltd 
dimerize to initiate transcription (see review by Laudet \& Gronemeyer (2002)). Dimer binding occurs upon initial binding of a monomeric receptor to the higher affinity DNA half-site followed by binding of the second receptor (Green et al. 1988, Tsai et al. 1988). Stabilization of this homodimer is achieved through protein-protein interactions involving specific amino acids in the second zinc finger of the receptors' DNA binding domains (DBD) (Dahlman-Wright et al. 1991). The GR and MR are activated by the same ligand (cortisol in mammals, corticosterone in rodents); recognize the same DNA sequence, called the glucocorticoid response element (GRE); and have long been known to homodimerize (GR-GR or MR-MR) upon ligand binding. Interestingly, despite the structural homology and extensive similarities in terms of DNA- and ligand-binding, surprisingly little is known about the interaction between the GR and MR aside from a few mammalian studies showing heterodimerization of the GR and MR in vitro (Trapp et al. 1994, Liu et al. 1995, Ou et al. 2001, Savory et al. 2001, Nishi et al. 2004) and in vivo (Gomez-Sanchez et al. 1990, Bradbury et al. 1994).

The corticosteroid signaling system in fish differs in some respects from that of tetrapods and is not yet fully understood. In fish, the major corticosteroid, cortisol, governs a plethora of physiological parameters, including hydromineral balance - a task performed by aldosterone in tetrapods. Due to the lack of $11 \beta$-hydroxylase, aldosterone synthesis is absent in fish (Jiang et al. 1998), seemingly leaving the MR with only cortisol as a ligand. However, the aldosterone synthesis intermediate 11-deoxycorticosterone (DOC), which is present in rainbow trout plasma in the nanomolar range (Milla et al. 2008, Kiilerich et al. 2011a), specifically binds and activates the MR with higher affinity than cortisol (Sturm et al. 2005). Although the biological roles of DOC in humans and other vertebrates have recently been reconsidered (reviewed by Vinson (2011)), the physiological relevance of DOC in osmoregulation in fish is still not established (Kiilerich et al. 2007, 2011a, b, c, McCormick et al. 2008). Notably, concurrent with the high expression and localization of the MR in the mammalian brain, the MR and DOC have recently been suggested to be involved in the regulation of fish behavior (Sakamoto et al. 2011). Compared to mammals, two GR isoforms have been described in fish in several phylogenetic superorders, such as rainbow trout (Bury et al. 2003), carp (Stolte et al. 2008a, b), medaka (Kim et al. 2011), stickleback (ENSEMBL), pufferfish (ENSEMBL) and Burtons mouthbrooder (Greenwood et al. 2003). Whole-genome duplication in the teleost lineage $\sim 350$
MYA gave rise to two GR isoforms, GR1 and GR2, with an identical domain structure and many similarities in terms of ligand- and DNA-binding (reviewed by Bury \& Sturm (2007) and Li et al. (2012)). Differential tissue mRNA expression levels and regulation of expression (Greenwood et al. 2003, Stolte et al. 2008a, Kiilerich et al. 2011a, Trayer et al. 2013), together with dissimilar $\mathrm{EC}_{50}$ values for cortisol (Bury et al. 2003, Greenwood et al. 2003, Stolte et al. 2008b, Kim et al. 2011, Li et al. 2012), suggest functional differences between these two GR subtypes.

Furthermore, differential activation of GR1, GR2 and $\mathrm{MR}$ are suggested based on the different cortisol $\mathrm{EC}_{50}$ values in vitro, where basal cortisol levels constitutively activate MR and GR2, while stress-induced cortisol levels are necessary to activate GR1 (reviewed by Kiilerich \& Prunet (2011)). This suggests, together with co-localization of the MR with GR1 in transporting epithelial cells such as intestinal, gill and kidney cells in trout (Kiilerich et al. 2011a), that cortisol signaling in fish could be mediated by both homo- and heterodimerization of the corticosteroid nuclear receptors, as shown in mammals.

The potential for transcriptional regulation via the interaction between the MR and GR has never been explored in fish despite several studies carried out in mammals. This prompted us to undertake a comparative study of the transcriptional activities of these corticosteroid receptors (CRs) in vitro and to investigate whether these fish receptors interact to modify their mutual transcriptional activities. The present study was conducted using the rainbow trout CRs, rtGR1, rtGR2 and rtMR.

\section{Materials and methods}

\section{Cell culture}

COS-7 cells were grown in DMEM GlutaMAX (Invitrogen) supplemented with $100 \mathrm{IU} / \mathrm{ml}$ penicillin, $100 \mu \mathrm{g} / \mathrm{ml}$ streptomycin (Biowest, Nuaillé, France) and 10\% decomplemented $\left(1 \mathrm{~h}\right.$ at $\left.56^{\circ} \mathrm{C}\right)$ fetal bovine serum (FBS) (Biowest) in a humidified atmosphere with $5 \% \mathrm{CO}_{2}$. Four hours before transfection and throughout the rest of the experiment, cells were maintained in DMEM GlutaMAX with $100 \mathrm{IU} / \mathrm{ml}$ penicillin, $100 \mu \mathrm{g} / \mathrm{ml}$ streptomycin and 2.5\% double dextran/coated, charcoal-treated FBS to remove steroids.

\section{Transient transfections}

Cells at 40-50\% confluence were transiently transfected with $0.6 \mu$ l FuGENE 6 (Roche Applied Science) and 175 ng

Published by Bioscientifica Ltd. 
plasmid DNA in a total volume of $100 \mu \mathrm{l}$ (completed with DMEM) per well in a 24-well plate. Plasmid mixes were as follows in ng/well: 50 pCMV-rtGR1 (Ducouret et al. 1995) or pCMV-rtGR2 (Bury et al. 2003); 5, 10 or 25 pCMV-rtMR (Sturm et al. 2005); empty pCMV-vector to normalize pCMV-load between wells; $50 \mathrm{pSV} \beta$ (Clontech) for $\beta$-galactosidase normalization; and 50 pCF3-Luci (containing the MMTV promoter with four GREs), pGL3GRE2-Luci (containing two GREs) or pTAT3-tkLuci (containing three GREs) as luciferase reporter plasmids. Twelve hours after transfection, steroids (cortisol or DOC (Sigma-Aldrich)) were added from 1000-fold concentrated stock solutions in ethanol and incubated for $24 \mathrm{~h}$ before harvesting in $100 \mu \mathrm{l}$ reporter lysis buffer (Promega) and analysis of luciferase and $\beta$-galactosidase.

For determination of the absolute mRNA levels of co-transfected steroid receptors by quantitative PCR, cells from each well were lysed in $500 \mu \mathrm{l}$ TRIzol (Invitrogen), and total RNA was extracted according to the manufacturer's recommendations using glycogen to precipitate the RNA.

For determination of co-transfected CR protein levels, cells were grown to $\sim 70 \%$ confluency in six-well plates before transfection with $650 \mathrm{ng}$ pCMV-rtGR1 or pEGFP-rtGR2 per well and $0,65,130$ or $325 \mathrm{ng}$ pCMV-rtMR per well using $3 \mu \mathrm{l}$ FuGENE 6 and DMEM to a total volume of $50 \mu \mathrm{l}$. Cells were harvested after $24-48 \mathrm{~h}$. The MR specific antagonist eplerenone (Sigma-Aldrich) was used to investigate the significance of a ligand activated MR.

\section{Luciferase and $\beta$-galactosidase activities}

Luciferase activities were determined using $10 \mu \mathrm{l}$ of cell lysate and $50 \mu$ of luciferase assay substrate (Promega) in white 96-well plates measured on a Synergy 2 plate reader (BioTek, Winooski, VT, USA). $\beta$-galactosidase measurements to adjust for well-specific transfection efficiency were carried out with $50 \mu \mathrm{l}$ of cell lysate and $200 \mu \mathrm{l}$ of substrate solution (final concentrations: $3 \mathrm{mM}$ o-nitrophenyl $\beta$-D-galactopyranoside, $0.56 \mathrm{M}$ potassium phosphate, $1 \mathrm{mM} \mathrm{MgCl} 2,44 \mathrm{mM} \beta$-mercaptoethanol) in transparent 96-well plates. After incubation at $37^{\circ} \mathrm{C}$ for $30-40 \mathrm{~min}$, absorbance at $405 \mathrm{~nm}$ was read.

The normalized luciferase activity was expressed as the fold induction compared to mock wells (transfected only with the luciferase-reporter and $\beta$-galactosidase vector). All experiments were performed in triplicate and repeated at least three times.

\section{RT and qPCR}

Reverse transcription of $0.3 \mu \mathrm{g}$ RNA was performed for $1 \mathrm{~h}$ at $37^{\circ} \mathrm{C}$ using $1 \mu \mathrm{g}$ Random Primers (Promega), $0.5 \mathrm{mM}$ dNTPs (Promega), 15 units RNasin (Promega) and 200 units MMLV reverse transcriptase (Promega) in a total volume of $25 \mu \mathrm{l}$. One microliter of cDNA was subjected to real-time PCR with SYBR Green PCR Master Mix in a total volume of $20 \mu \mathrm{l}$ on a StepOne Plus real time PCR machine (Applied Biosystems, Life Technologies). Cycling conditions were $95^{\circ} \mathrm{C}$ for $20 \mathrm{~s}$ for initial denaturation, followed by 40 cycles of $95^{\circ} \mathrm{C}$ for $3 \mathrm{~s}$ and $60^{\circ} \mathrm{C}$ for $30 \mathrm{~s}$ before a melt curve stage.

Ct values from the transfected cell samples were transformed into absolute copy numbers using standard curves from dilution series of pCMV-rtGR1, -rtGR2 and rtMR from 106 to 1011 copies.

Primer sequences were as follows: rtGR1 forward 5'-CCATCGTCAAGCGGGAAGAG-3' (Z54210 nucleotide position 3245-3264), rtGR1 reverse 5'-GGAACTCCACGCTAAGGGATTTATTC-3' (Z54210 nucleotide position 3394-3369), rtGR2 forward 5'-CTCCGCTTTCTCCAGCAGCTA-3' (AY495372 nucleotide position 1473-1493), rtGR2 reverse 5'-GTGAGCCACCCCGTAGTGACAG-3' (AY45372 nucleotide position 1622-1602), rtMR forward 5'-GAAACAGATGATCCGCGTGGT-3' (AY495584 nucleotide position 2941-2962) and rtMR reverse 5'-TGGATCAGGGTGATTTGGTCCT-3' (AY495584 nucleotide position 3027-3006). $\beta$-galactosidase primers were used to normalize between wells according to transfection efficiency, using forward 5'-ACTATCCCGACCGCCTTACT-3' (pSV $\beta$ vector nucleotide position 3988-3407) and reverse $5^{\prime}$-CTGTAGCGGCTGATGTTGAA-3' (pSV $\beta$ vector nucleotide position 3562-3543) primers.

\section{Western blotting}

Proteins were harvested from transiently transfected COS-7 cells after two to three washes in PBS by adding $75 \mu \mathrm{l}$ of RIPA buffer (1\% NP-40, 0.5\% sodium deoxycholate, $0.1 \%$ SDS, $50 \mathrm{mM}$ Tris $\mathrm{pH} 7.4-7.5,150 \mathrm{mM} \mathrm{NaCl}$, $10 \%$ glycerol, $1 \mathrm{mM}$ EDTA) supplemented with antiprotease cocktail (Sigma) and left for $10 \mathrm{~min}$ at $4{ }^{\circ} \mathrm{C}$ with light shaking. Cell extracts were transferred to eppendorf tubes and incubated on ice for $10 \mathrm{~min}$ before pelleting at $16000 \mathrm{~g}$ for $10 \mathrm{~min}$ at $4{ }^{\circ} \mathrm{C}$. The supernatants were transferred to fresh tubes and protein concentrations determined using the Bradford method.

$20 \mu \mathrm{g}$ of protein with $5 \mu \mathrm{l}$ of loading buffer was denatured at $99{ }^{\circ} \mathrm{C}$ for 5 min before running on a $10 \%$

Published by Bioscientifica Ltd 
acrylamide gel including the Precision Plus Western $\mathrm{C}$ protein marker (Bio-Rad). Proteins were transferred by submerged blotting to an Amersham Hybond-C Extra membrane (GE Healthcare, Little Chalfont, Buckinghamshire, UK) before blocking for $2 \mathrm{~h}$ at RT in Tris-buffered saline + Tween (TBST) with 5\% milk. The membranes were incubated overnight at $4{ }^{\circ} \mathrm{C}$ with primary antibodies (rabbit anti-rtMR 1/1000 dilution (Kiilerich et al. 2011a); rabbit anti-rtGR1 1/2000 dilution (Tujague et al. 1998), mouse anti-GFP $1 / 2000$ dilution (JL-8, Clontech) and mouse anti- $\beta$-actin 1/3000 dilution (sc-47778, Santa Cruz Biotechnology). After washing in TBST, the membranes were incubated for $1 \mathrm{~h}$ at RT with a secondary antibody (anti-rabbit-HRP and/or anti-mouse-HRP in 1/20000 dilution in TBST $+5 \%$ milk) with a StrepTactin-HRP anti-protein marker antibody (1/5000 dilution, Bio-Rad). Membranes were revealed using UptiLight WB HRP chemiluminescence substrate (Uptima, Interchim, Montluçon, France) on a Fusion Fx7 (Vilber-Lourmat, Marne-la-Vallée, France) with standard settings.

\section{Subcellular localization of the rainbow trout GRs in the presence of rtMR}

COS-7 cells were transfected as described above using 100 ng pEGFP-rtGR1 and pEGFP-rtGR2 and pCMV-rtMR at a ratio of $1: 5$ and 1:2, respectively, in 24 well plates. The next day, wells were treated with cortisol $\left(10^{-7}\right.$ and $10^{-8} \mathrm{M}$ for GR1 and GR2, respectively) and/or eplerenone $\left(10^{-5} \mathrm{M}\right)$ for $4 \mathrm{~h}$, and then washed with PBS before visualization. GFP-tagged rtGR1 and rtGR2 were a kind gift from Armin Sturm and Nic Bury (Becker et al. 2008).

\section{Subcellular localization of the rtMR and co-localization of the rtMR and rtGRs}

rtMR cDNA was excised from the pCMV-vector using the EcoRI and HindII sites and subcloned into the pDsRedMonomer-C1 vector (Clontech), tagging the rtMR with a red fluorescent protein on the $\mathrm{N}$-terminal end. Positive clones were sequenced to verify the correct orientation and reading frame. For cellular localization studies, COS-7 cells were plated on $35 \mathrm{~mm}$ WillCo dishes (WillCo Wells BV, Amsterdam, The Netherlands) at 50000 cells/well and transfected as described above with $2.8 \mu \mathrm{g}$ vector per dish and left overnight. The cells were transfected with pDsRed-rtMR, pDsRed empty vector, pEGFP-rtGR1, pEGFP-rtGR2 and combinations of the constructs (1:1). The cells were viewed in DMEM without serum, and the dishes were placed in a chamber at a constant temperature of $37^{\circ} \mathrm{C}$ throughout the experiment. The cells were examined using a TCS SP5X Confocal microscope (Leica, Heidelberg, Germany) with a $63 \times$ water objective (1.2 NA) using a white light laser GFP, and DsRed. Four images were acquired after 488 and $543 \mathrm{~nm}$ excitation respectively. Emission was collected at 500-525 (GFP) and 605-650 (DsRed) to minimize bleed through. For co-localization studies, sequential scans (line by line) were used to completely avoid bleed through. After the addition of cortisol (final concentration $10^{-7} \mathrm{M}$ for GR1 and $10^{-8} \mathrm{M}$ for GR2 and MR), the cells were placed in the incubator and viewed again after $1 \mathrm{~h}$.

\section{Statistical analyses}

All experiments were conducted at least three times. Transfections were performed in triplicate, and a representative result is presented here; all values are presented as the mean \pm s.E.M. $(n=3)$. Significant differences between treatments (control vs hormone) and within treatments (control or hormone) were detected with two-way and one-way ANOVA, respectively, followed by multiple $t$-tests with Bonferroni correction using GraphPad Prism 5 software.

\section{Results}

\section{The rainbow trout MR is a weaker transcriptional regulator compared to rtGR1 and rtGR2}

To compare the transcriptional activity between the rainbow trout CRs, we transfected the same amount of CR-expressing vector in COS-7 cells using an MMTVcontaining promoter (pCF3) including four GREs as the reporter gene. The maximal cortisol-mediated transcriptional activity of the MR (7.5-fold induction) was significantly lower compared to both GR1 and GR2 (620- and 700-fold induction, respectively, Fig. 1A). The lower MR-mediated transcriptional activation was also observed on two different GRE-containing promoters (Fig. 1B and C).

The MMTV promoter is a naturally occurring, rather complex promoter. It contains four GR binding sites with slightly different similarity to the consensus GRE sequence, where at least one of them is highly activated by the GR (Payvar et al. 1983, Ham et al. 1988). Furthermore, Meijsing et al. (2009) demonstrated that as little as one nucleotide change in a GRE sequence was able to confer changes in the transcriptional activity of the GR; thus, the GRE sequence might also influence the effect of transfected receptors. We therefore employed more simple promoters with different

Published by Bioscientifica Ltd. 

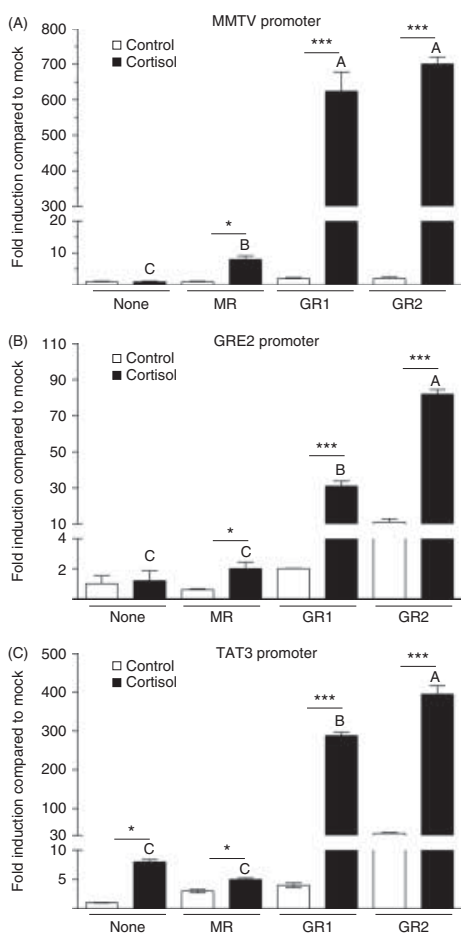

Figure 1

Transcriptional activity of the rtMR is significantly lower than that of rtGR1 and rtGR2. Comparison of the transcriptional activity of rtMR, rtGR1 and rtGR2 in COS-7 cells with or without cortisol $\left(10^{-7} \mathrm{M}\right)$ as ligand on (A) MMTV-promoter (four GREs), (B) GRE2-promoter (two GREs) and (C) TAT3promoter (three GREs). Values with no letters in common are significantly different. ${ }^{*} P<0.05$ and $* * * P<0.001$.

GREs to investigate the nature of MR transactivation activity: the GRE2 promoter-reporter is an artificial promoter harboring two consensus GRE sequences and the TAT3 promoter-reporter containing three GREs from the tyrosine aminotransferase promoter. As seen in Fig. 1B and $\mathrm{C}$, the MR is a much weaker transcriptionally active on all promoters compared to the GR.

\section{Co-transfected MR impairs maximal GR1 and GR2-mediated transcriptional activation}

As the MR and GRs confer transcriptional activation from the same GRE-driven reporter plasmid, we investigated the functional consequences on GR and MR transcriptional activities after co-transfection. As expected, increased amounts of the MR alone (0-25 ng/well) gave rise to a parallel increase in reporter gene expression (Fig. 2A). A fixed amount of GR1 and GR2 (50 ng/well) was co-transfected with increasing amounts of MR (0-25 ng/well) and activated with cortisol. Interestingly, there was a significant decrease in maximal transcriptional activities of GR1 or GR2 when cotransfected with the MR in a dose-dependent manner (Fig. 2A left and right panels). GR1 activity was more affected by MR co-expression than GR2 activity, given that a GR1-to-MR ratio of 1:10 already resulted in a 50\% decrease of GR1 activity while a GR2-to-MR ratio of 1:2 was necessary to induce the same effect on GR2 activity. This was not due to an overload of receptor when using the maximal GR-to-MR ratio $(50+25 \mathrm{ng} /$ well $)$, because total GR2 transcriptional activity still increased from 50 to 75 ng GR2 per well (Supplementary Figure 1A, see section on supplementary data given at the end of this article). However, when using a higher amount of plasmid (100 ng GR2-plasmid per well) decreased transcriptional activity was observed (see Supplementary Figure 1A). Additionally, we also showed that the degree of MR-mediated inhibition on GR1 activity remained unchanged regardless of the amount of available GRE, as demonstrated by increasing the amount of MMTV plasmid (Supplementary Figure 1B), thus excluding the possibility that GRE-binding by GR constitutes a rate-limiting step. Of note, inhibition of GR transcriptional activities by the MR was obtained with considerably lower amounts of mRNA transcribed from the MR-expressing vector compared to GR-encoding plasmids, as shown in Fig. 2B. Furthermore, we verified that under these experimental conditions, decreased transcriptional activities were not associated with altered CR expression, as demonstrated by Western blot analysis in which GR1 and GR2 protein expression remained constant (Fig. 2C, left and middle panels, respectively) in the presence of increased amounts of MR protein (Fig. 2C right panel).

Collectively, these data clearly indicated that the MR significantly reduced transcriptional activities of trout GR1 and GR2 upon cortisol stimulation.

\section{Specific activation or antagonism of the MR does not affect the inhibition of GR activity}

To further investigate the mechanisms by which the MR inhibits GR transcriptional activities, co-transfections were carried out in the presence of specific MR agonist (DOC) or antagonist (eplerenone). Spironolactone, which is widely used in clinical practice for MR blockade, has been shown to exert agonistic activity on trout MR and thus cannot be used as a selective MR antagonist (Sturm et al. 2005). We thus tested a second-generation MR antagonist, eplerenone. As shown in Supplementary Figure 2A, see section on supplementary data given at the end of this article, increasing concentrations of

Published by Bioscientifica Ltd. 
(A)

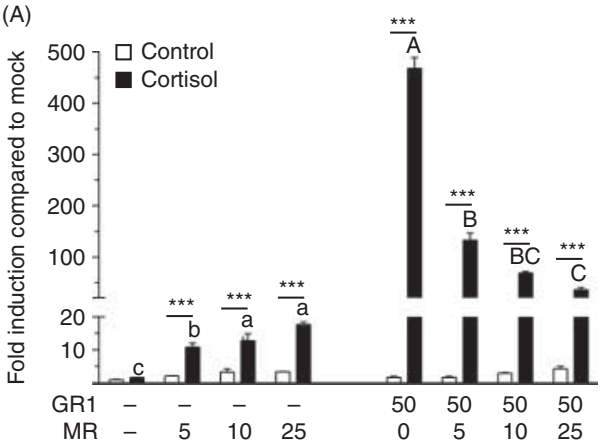

(B)

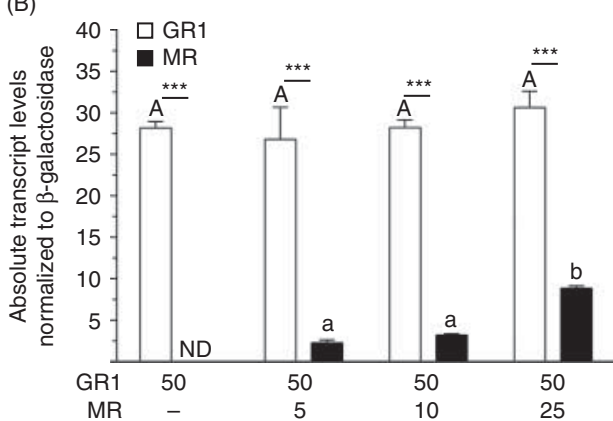

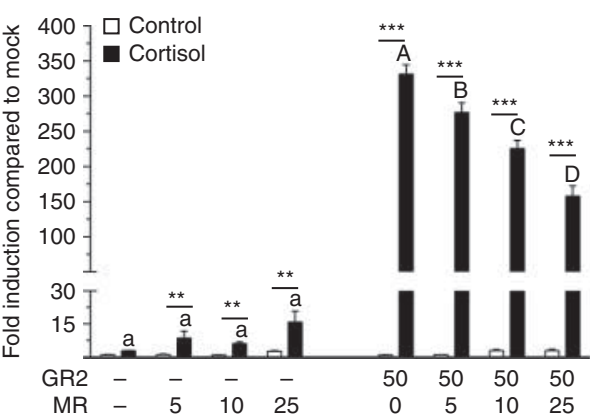

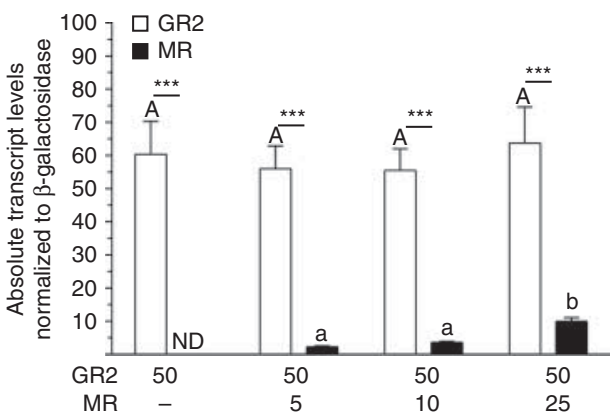

(C)
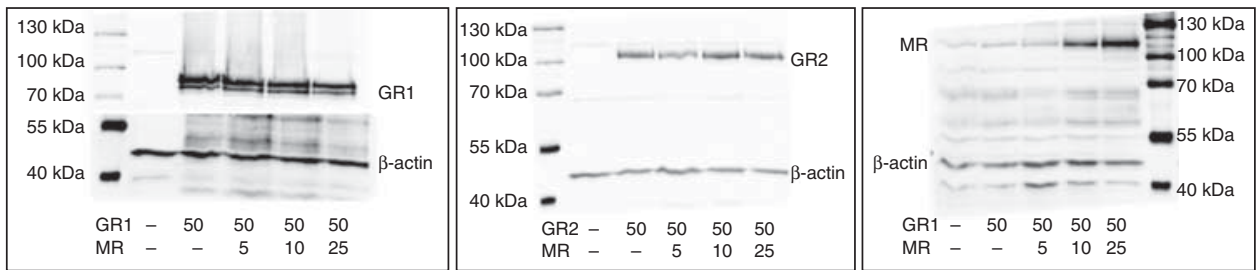

Figure 2

Co-transfection of GR1 and GR2 with MR decreases transcriptional activity. (A) Cells were transfected with increasing amounts of MR expression vector $(5,10$ or $25 \mathrm{ng} /$ well $)$ alone or co-transfected with a fixed amount of GR1 or GR2 expression vector ( $50 \mathrm{ng} / \mathrm{well})$ and incubated with cortisol $\left(10^{-7} \mathrm{M}\right.$ for GR1 and $10^{-8} \mathrm{M}$ for GR2 or vehicle for controls). (B) mRNA levels of cells transfected with a fixed amount of GR1 and GR2 alone or co-transfected

eplerenone (from $10^{-6}$ to $10^{-5} \mathrm{M}$ ) showed a dosedependent inhibition of transactivation activity of the $\mathrm{MR}$ in presence of $10^{-8} \mathrm{M}$ cortisol. However, that inhibition was not observed in presence of $10^{-7} \mathrm{M}$ cortisol.

When the MR was specifically activated by $10^{-8} \mathrm{M}$ DOC simultaneously with $10^{-8} \mathrm{M}$ cortisol activating GR1 or GR2, we observed the same inhibitory effect of the MR on GR1 or GR2 transactivation activity (Fig. 3A). Using the same concentration of cortisol and DOC in this experiment should have, in theory, favored DOC activation of the $\mathrm{MR}$ due to the tenfold lower $\mathrm{EC}_{50}$ value for $\mathrm{DOC}$ compared to cortisol on the rtMR $(0.1$ and $1.1 \mathrm{nM}$ respectively). with increasing amounts of MR as determined by RT-qPCR. (C) Western blot analysis of the protein levels in transfected cells. The amounts of GR1 and EGFP-GR2 were fixed while the amount of MR was increased. $\beta$-actin was used a loading control. Values with no lowercase or uppercase letters in common are significantly different. $* * P<0.01$ and $* * * P<0.001$.

To further investigate whether a ligand-activated MR was required for the observed inhibition, we validated the use of the MR antagonist eplerenone at a $10^{-5} \mathrm{M}$ concentration together with $10^{-8} \mathrm{M}$ cortisol (Supplementary Figure 2B). Because the $10^{-8} \mathrm{M}$ cortisol concentration is not sufficient to activate GR1 (22), we investigated the effect of eplerenone only on GR2, which is more sensitive to cortisol. As expected, eplerenone inhibits MR activation but does not affect GR2 cortisol activation (Fig. 3B). Moreover, specific inhibition of MR activity with eplerenone did not affect GR2-mediated transcriptional activity (Fig. 3B, right panel), suggesting that the MR-mediated inhibition of GR2 activity is not dependent on a transcriptionally active MR.

Published by Bioscientifica Ltd 
(A) $\square$ Control $\square$ Cortisol $\square$ Cortisol+DOC $\square$ DOC
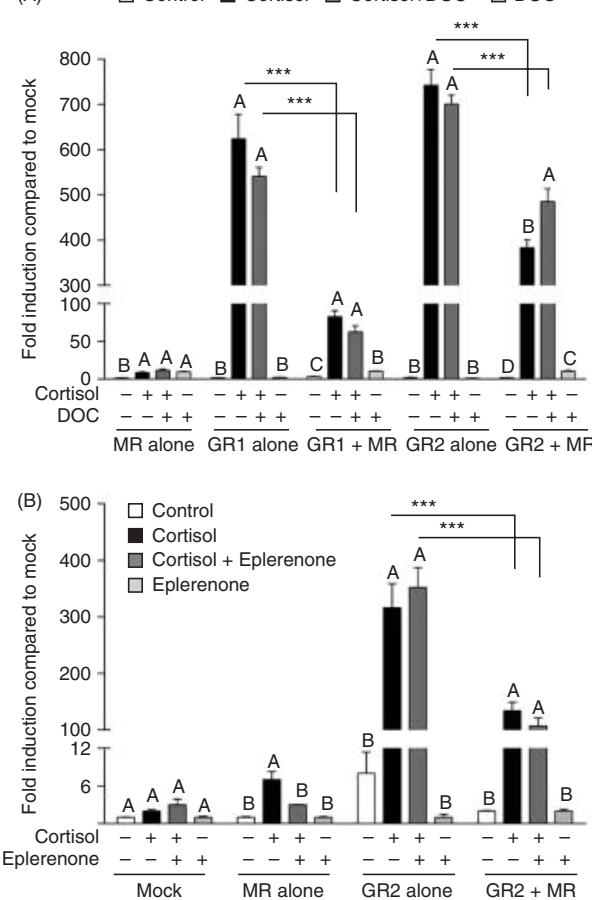

(C)
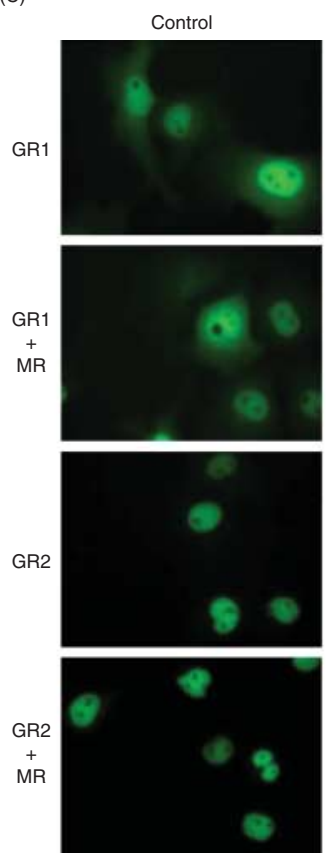

Cortisol
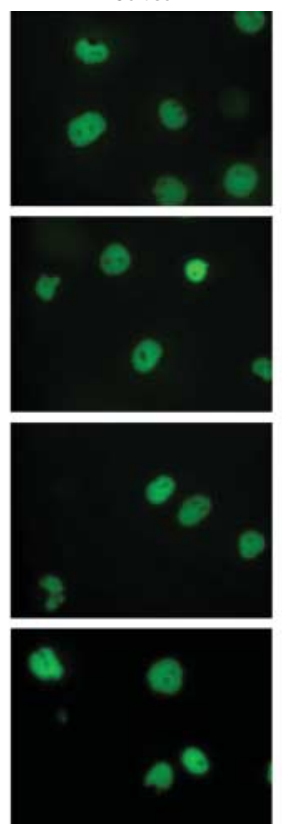

Cortisol + Eplerenone
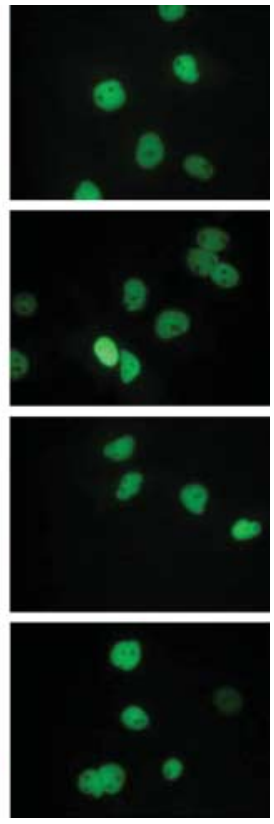

\section{Figure 3}

Specific activation or inhibition of MR does not affect the repressive effect. (A) Cells were transfected with GR1 or GR2 (50 ng/well), co-transfected with MR (10 and $25 \mathrm{ng} /$ well with GR1 and GR2, respectively) and added cortisol $\left(10^{-7} \mathrm{M}\right.$ for GR1 and $10^{-8} \mathrm{M}$ for GR2) and/or DOC $\left(10^{-8} \mathrm{M}\right)$. (B) Cells were transfected with GR2 and co-transfected with MR and treated with cortisol

\section{Co-transfection of the MR does not affect subcellular localization of the GR}

To determine whether the inhibitory effect of the MR was due to altered subcellular localization of the GRs, we co-transfected GFP-tagged GR1 and GR2 with and without the MR. Like previous localization studies of rtGRs in mammalian cell lines (Becker et al. 2008), we found that rtGR1 localized in both the cytoplasm and the nucleus in the absence of a ligand (Fig. 3C), with a complete nuclear translocation upon ligand treatment, while rtGR2 was mainly localized in the nucleus independent of cortisol treatment (Fig. 3C). Co-transfection with the MR did not modify the subcellular localization of GR1 or GR2, and there was no effect of specific antagonism of the MR using eplerenone (Fig. 3C). These data agree with Nishi et al. (2001) who showed that subcellular localization of the rat GR was not modified upon co-transfection with the rat MR. This also suggests that MR mediated inhibition of GR activity is not related to the MR-induced modification of the cellular localization of cortisol-activated GR. $\left(10^{-8} \mathrm{M}\right)$ or eplerenone $\left(10^{-5} \mathrm{M}\right)$. Values with no letters in common within one group (MR alone, GR1 alone, GR1 + MR, etc.) are significantly different. $* * * P<0.001$. (C) Subcellular localization of EGFP-rtGR1 and EGFP-rtGR2, with or without co-transfected MR and with or without cortisol $\left(10^{-7} \mathrm{M}\right.$ for GR1 and $10^{-8} \mathrm{M}$ for GR2) or eplerenone $\left(10^{-5} \mathrm{M}\right)$.

\section{Subcellular localization of MR}

Red fluorescent protein DsRed-tagged receptors were used to analyze the subcellular localization of the rtMR in COS cells. Whereas the DsRed protein was found in the cytoplasm and the nucleus, as expected, the DsRed-rtMR was clearly localized to the nucleus. After the addition of cortisol $\left(10^{-9} \mathrm{M}\right)$, no modification was observed in the control or in the MR-transfected cells, and the red fluorescence remained located clearly in the nuclear compartment (Fig. 4A). When co-transfected with GR1 and GR2, the MR was clearly co-localized with these receptors in the nucleus both with and without the ligand (Fig. 4B). These data suggest that co-expression of CRs might result in co-localization of both receptors in the nucleus without direct evidence of a physical interaction between them.

\section{Genetic analysis of GR-MR interactions at the level of the DBD domain}

Studies using mammalian steroid receptors transfected in monkey cell lines have shown that the GR and the MR

Published by Bioscientifica Ltd 
(A)

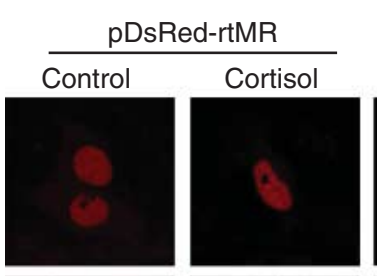

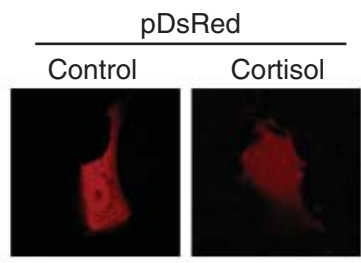

(B)
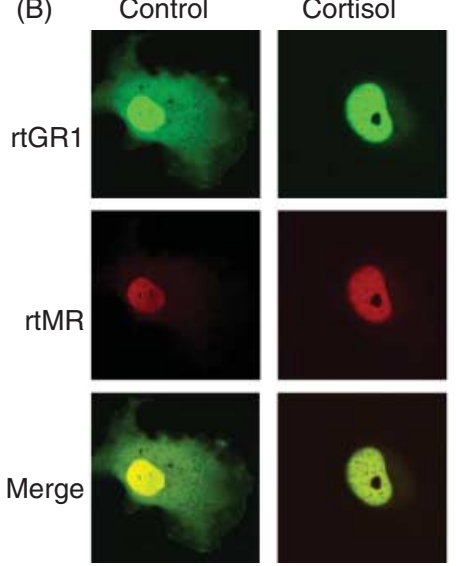
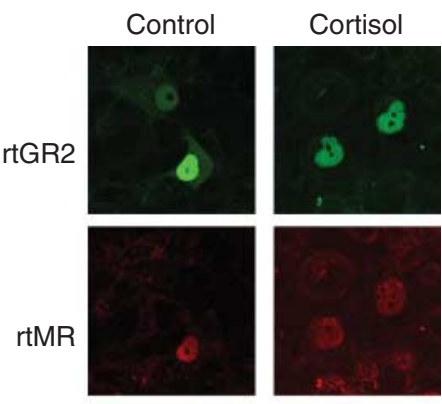

Merge
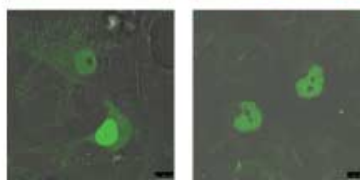

\section{Figure 4}

Subcellular localization of MR and co-localization with GR. (A) rtMR was tagged with DsRed and localized with or without $10^{-8} \mathrm{M}$ cortisol using fluorescence microscopy. (B) Co-transfection of rtMR-DsRed with rtGR1-GFP

can functionally interact at the transcriptional level through heterodimer formation on a GRE element (Liu et al. 1995). Moreover, this heterodimer interaction involves a DBD dimer interface whose role is not only to stabilize receptor occupancy but also to curtail receptor self-synergy (Liu et al. 1995, Chen et al. 1997). In view of the capability of the GR to self-synergize on multiple GRE and of the impossibility for MR to do so, it has been suggested that inhibition of GR activity by the MR could be explained by formation of a heterodimer that was incapable of self-synergy (Liu et al. 1995). Moreover, Liu et al. (1995) also propose that the N-terminal region of the MR disrupts the GR self-synergy when the two receptors are brought into contact with each other. In this context, we wanted to examine whether such mechanism also occurs with trout MR-GR interactions. or GR2-GFP shows subcellular co-localization of the MR and the GRs $\left(10^{-7} \mathrm{M}\right.$ cortisol for GR1 and $10^{-8} \mathrm{M}$ cortisol for GR2).

To carry out such tasks, various point-mutated MR receptors have been generated that include single aminoacid mutations in the DBD (two forms: $\mathrm{MR}_{\mathrm{DBD}} \mathrm{C}-\mathrm{G}$ and $\mathrm{MR}_{\mathrm{DBD}} \mathrm{S}-\mathrm{R}$ ) or in the second zinc finger of the $\mathrm{DBD}$ (involved in the dimerization interface: $\mathrm{MR}_{\mathrm{DIM}} \mathrm{R}-\mathrm{D}$ and $\mathrm{MR}_{\text {DIM }} \mathrm{D}-\mathrm{R}$ ) (Supplementary Figure 3, see section on supplementary data given at the end of this article).

As expected, when analyzing transactivation properties of the mutated MR forms, mutations in the DBD decreased (Cys to Gly) or fully abolished (Ser to Arg) the transcriptional activity, whereas interruption of the dimerization ability (both DIM mutations equally) significantly increased the transcriptional activity of the MR on all promoters investigated in this study (Fig. 5A and Supplementary Figure 4, see section on supplementary data given at the end of this article). The latter is in good
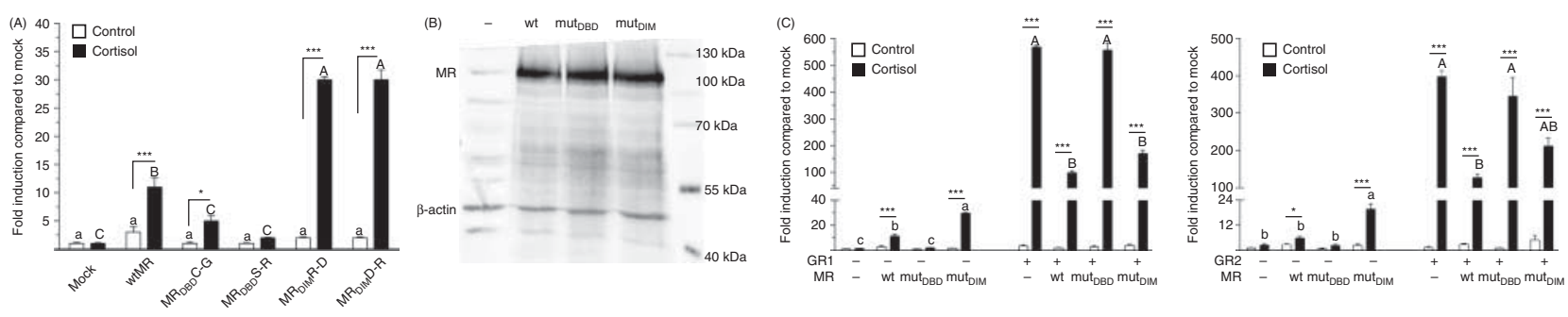

\section{Figure 5}

(A) Transcriptional activity of wtMR and the different mutated MRs on the MMTV-promoter; DNA-binding domain mutants: $\mathrm{MR}_{\mathrm{DBD}} \mathrm{C}-\mathrm{G}$ (cysteine mutated to glycine) and $M R_{D B D} S-R$ (serine mutated to arginine) and dimerization domain mutants: $\mathrm{MR}_{\mathrm{DIM}} \mathrm{R}-\mathrm{D}$ (arginine mutated to aspartic acid) and $M R_{D I M} D-R$ (aspartic acid mutated to arginine). Cortisol concentration $10^{-8} \mathrm{M}$. Values with no lowercase (controls) or uppercase (cortisol treated) letters in common are significantly different. (B) Western

blot showing protein expression levels of wtMR, MR $\mathrm{DBD}_{\mathrm{D}}$ and $M \mathrm{R}_{\mathrm{DIM}}$ in a co-transfection with GR1, $* P<0.05, * * * P<0.001$. (C) Co-transfection of GR1 or GR2 with wtMR, $M_{\mathrm{DBD}}$ (serine to arginine mutation) and $\mathrm{MR}_{\mathrm{DIM}}$ (arginine to aspartic acid mutation) on the MMTV-promoter. Cortisol concentration $10^{-7} \mathrm{M}$ for GR1 and $10^{-8} \mathrm{M}$ for GR2. Values with no lowercase (MR alone) or uppercase (co-transfection of MR with GRs) letters in common are significantly different.

Published by Bioscientifica Ltd 
agreement with previous studies in mammals where mutations in the dimerization domain increased MR, GR and AR activities when tested on promoters containing multiple GREs (Liu et al. 1996, Chen et al. 1997, Adams et al. 2003). Western blot analysis of the wtMR, $\mathrm{MR}_{\mathrm{DBD}}$, and $\mathrm{MR}_{\mathrm{DIM}}$ was evaluated to confirm that the lack of inhibition by the $\mathrm{MR}_{\mathrm{DBD}}$ was not due to an unduly breakdown of this mutated receptor (Fig. 5B).

Due to the significant effect of the serine-to-arginine mutation on MR transactivation activity, we decided to continue our study using only the $\mathrm{MR}_{\mathrm{DBD}} \mathrm{S}-\mathrm{R}$ (Ser to Arg) mutant. Furthermore, because the effect of either mutation in the salt bridge amino acids was identical, we chose to further investigate the $\mathrm{MR}_{\mathrm{DIM}} \mathrm{R}-\mathrm{D}$ (Arg to Asp) mutant.

Using the MMTV promoter, a mutation in the DBD $\left(\mathrm{MR}_{\mathrm{DBD}}\right)$ of the MR fully abolished the inhibitory effect of the wtMR on GR1 and GR2 activity, whereas $\mathrm{MR}_{\mathrm{DIM}}$ always impaired the GR activity (Fig. 5C, right and left graphs). While the $\mathrm{MR}_{\mathrm{DIM}}$ mutant significantly reduces GR1 activity and displays similar inhibition compared to the wtMR, the $\mathrm{MR}_{\mathrm{DIM}}$ yielded an intermediate response between the wtMR and the mutated $\mathrm{MR}_{\mathrm{DBD}}$ with GR2. Thus, the inhibitory effect of the MR on GR1 and GR2 activity seems to be essentially dependent on DNAbinding but does not necessarily require a dimerization interface. Such results are in agreement with the nuclear co-localization of the MR and GR1 or GR2 in COS cells as indicated above (see Fig. 4B).

\section{Influence of the response element sequence on the repressive effect of the MR}

When comparing various GRE containing promoters, the effects of the DBD and dimerization mutations on MR activity are largely comparable among the MMTV, GRE2 and TAT3 promoters: the $\mathrm{MR}_{\mathrm{DBD}}$ alone has little or no transactivation activity whereas the $\mathrm{MR}_{\mathrm{DIM}}$ alone is more transcriptionally active than the wtMR (see Figs 5 and 6). The lack of transcriptional activity by the $\mathrm{MR}_{\mathrm{DBD}}$ might question the functionality of this mutant receptor, but the $\mathrm{MR}_{\mathrm{DBD}}$ shows equal transcriptional activity to that of wtMR on the TAT3 promoter (Fig. 6B left panel), suggesting that the point mutation did not disrupt protein structure and function or abolish the DNA-protein recognition.

However, despite similar effects of mutations on MR activity, the effects of the $\mathrm{MR}_{\mathrm{DBD}}$ and the $\mathrm{MR}_{\mathrm{DIM}}$ on GR1 and GR2 activity tested with the various promoters are somewhat different. As expected, the $\mathrm{MR}_{\mathrm{DBD}}$ is unable to inhibit GR2 activity on both the GRE2 and TAT3 promoters in agreement with the specificity of the DNA response element. However, this mutant has only a partial inhibitory effect on GR1 activity compared to the wtMR on GRE2 or TAT3 promoters. The $\mathrm{MR}_{\mathrm{DIM}}$ is an equally good inhibitor of GR2 activity on the GRE2 compared to the wtMR, while $\mathrm{MR}_{\mathrm{DIM}}$ has partially lost the inhibitory effect on both GR1 and GR2 on the TAT3-promoter and only GR1 on the GRE2-promoter (Fig. 6).

\section{Interaction of the human GR and MR}

To investigate whether the dominant-negative effect of the MR on GR activity in trout could be mimicked to mammalian receptors under the same conditions (cell line and promoter constructs), human GR (hGR) and MR (hMR) were co-transfected in COS-7 cells together with the three different promoter-reporter constructs: MMTV, GRE2 and TAT3. Co-transfection of hGR with hMR resulted in decreased total transcriptional activity on all three promoters (Fig. 7). Notably, the pattern of inhibition was not identical between the promoters, underlining the
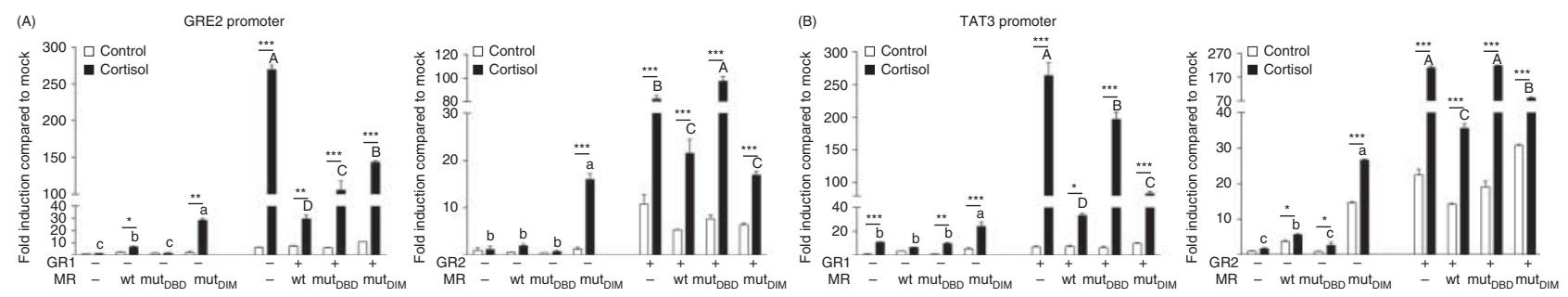

Figure 6

MR inhibition of GR1 and GR2 activity on different promoters in COS-7 cells. Transcriptional activity of wtMR, $\mathrm{MR}_{\mathrm{DBD}}$ and $\mathrm{MR}_{\mathrm{DIM}}$ alone and effect of wtMR, MR $R_{D B D}$ and MR $R_{D I M}$ on GR1 and GR2 activities on GRE2 (A) and TAT3 (B) promoters. Cortisol concentration $10^{-7} \mathrm{M}$ for GR1 and $10^{-8} \mathrm{M}$ for GR2.

Values with no lower case (MRs alone) or uppercase (co-transfection of MRs with GRs) letters in common are significantly different, $* P<0.05, * * P<0.01$ and $* * * P<0.001$. 

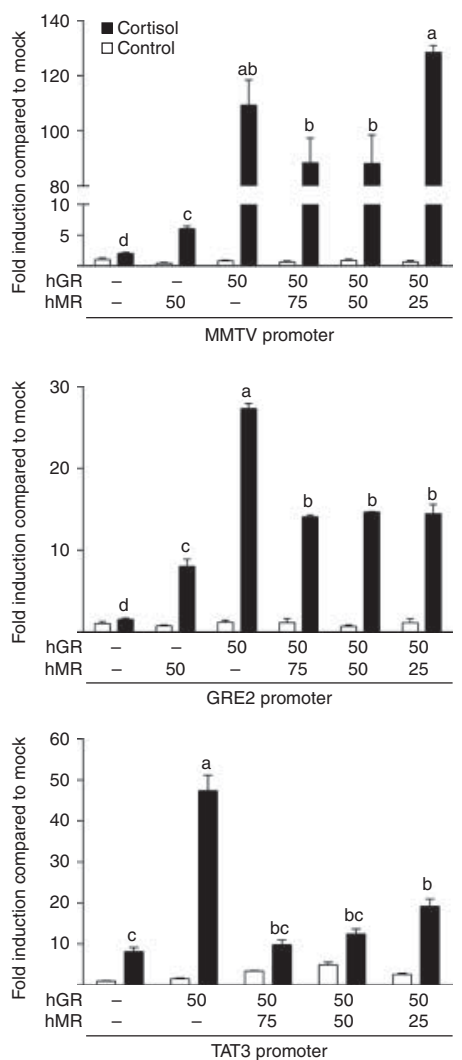

Figure 7

Human MR exerts promoter-specific dominant-negative effect on human GR activity. COS-7 cells were co-transfected with human GR and increasing amounts of human MR together with one of the following promoters, MMTV, GRE2 or TAT3 respectively. Cortisol concentration $10^{-7} \mathrm{M}$. Values with no letters in common are significantly different.

promoter specificity also observed when using the trout CRs. Despite the amount of MR needed to obtain inhibition being much higher for the human receptors (equal amounts or more of the MR compared to the amount of the GR) compared to fish, the results suggest similar mechanism of dominant-negative inhibition by the MR on GR activity.

\section{Discussion}

The present study aims to address the functional relevance of the rainbow trout MR and to examine its potential transactivation interference with rtGR activity. The MR and the two GR isoforms (rtGR1 and rtGR2) in fish are, as in mammals, CRs with similar DNA- and hormonebinding ability (GRE and cortisol, respectively) even though the MR exhibits significantly lower ligand-mediated transcriptional activity when compared to both GR1 and GR2. These receptors have been shown to co-localize in the same cell types in vivo (Kiilerich et al. 2011a), which questions the functional activity of the MR. However, besides cortisol, 11-deoxycorticosterone (DOC) has been identified as a ligand for the MR, suggesting the presence of a MR-DOC signaling pathway as this steroid was shown to be a more potent enhancer of MR transcriptional activity than cortisol (Sturm et al. 2005). Moreover, based on the results presented in this paper, we suggest that the MR, at least in part, could act as a repressor of GR activity. The extent of interaction between endogenous MR and GRs on natural target gene GREs in different cell types has still to be investigated in order to fully understand the physiological consequences of this mechanism.

In this study, we report significant repression of GR activity when co-transfected with the MR - even at relatively low levels of MR compared to GR. This MR-mediated repression of GR activity has also been described in mammals and seems to be a typical outcome of GR and MR co-localization (Liu et al. 1995, Derfoul et al. 1998, Ou et al. 2001, Planey et al. 2002), although synergistic transcriptional activation between the GR and the MR was also described by Trapp et al. (1994). Such observations of mutual inhibition of transcriptional activity have also been described with androgen and GRs, which is consistent with a high degree of sequence homology in the dimer interface of DBD between these nuclear receptors (Chen et al. 1997). In all of these studies, the inhibition of nuclear receptor transactivation activity is associated with mechanisms involving heterodimerization formation that have been demonstrated through gel shift (EMSA) experiments (Liu et al. 1995, Chen et al. 1997, Ou et al. 2001). Based on previous reports using mammalian GR and MR, the MR-GR heterodimer results in a disruption of the self-synergistic capacity of the GR at multiple GREs, a property that is not observed with the MR (Rupprecht et al. 1993, Liu et al. 1995). Disruption of such self-synergistic capacity by interaction between the $\mathrm{N}$-terminal domains in the MR and the GR led to an inhibition of GR activity.

In this context, a similar mechanism of MR-mediated disruption of the self-synergistic capacity of the GR by MR-GR heterodimerization might exist in rainbow trout. However, studies using a single GRE-promoter seem necessary in order to fully conclude this theory. Interestingly, data from the present study support the existence of self-synergistic properties of MR in rainbow trout: when testing the rainbow trout $\mathrm{MR}_{\mathrm{DIM}}$ mutant, we observed a significant increase in its transcriptional activity when compared to the wtMR (Figs 5A and 5C, 6A and 6B).

Published by Bioscientifica Ltd 
This result is very similar to the increased transactivation activity observed with the mutated mammalian MR at the level of the DBD dimer interface (Liu et al. 1996). Altogether, our data suggests that MR exerts a dominantnegative effect on GR1 and GR2 activity as a way to regulate total transactivation activity in corticosteroid target tissues in fish. The interaction between MR and the GRs seems predominantly dependent on DNA-binding but might also to some extent be dependent on heterodimerization. Using point mutations of the MR this study clearly indicates that disruption of the MR DBD significantly reduces its repressor activity when co-transfected with the GR (Figs 5 and 6). This was more pronounced for GR2, where the inhibitory effect of MR was completely abolished with the DBD mutation on all promoters. A significant inhibition of GR1 activity was still observed with the $\mathrm{MR}_{\mathrm{DBD}}$ mutant, although to a lower degree than with wtMR, on the GRE2 and TAT3 promoters, suggesting that squelching of co-transcription factors by MR may also determine GR1 activity. However, the overall reduced inhibition by $\mathrm{MR}_{\mathrm{DBD}}$, which was observed in the present study on various promoters containing two or more GRE sequences, is in agreement with the essential role of this DNA-binding region located within the first zinc finger motif for the binding of the receptor on DNA (Rusconi \& Yamamoto 1987, Schena et al. 1989). As abolishment of the rtMR $\mathrm{DBD}_{\mathrm{DB}}$ mutant binding to the GRE motif is associated with a reduction in its repressor activity, this clearly indicates that the wtMR does interact with the GR at the DNA level. Further studies of the repressor activity of the mutated MR using point-mutations in the two heterodimerization amino acids in the second zinc finger suggest that heterodimerization of MR with the GRs might also be part of the dominant-negative effect of MR on GR activity.

These amino-acids are known in mammals to be involved in stabilizing the dimerization interface and are required for the cooperative DNA binding of the DBD domain on the GRE in vitro (Dahlman-Wright et al. 1991). In this context, the fact that the present study shows a significantly reduced repressor activity of the mutated MR when tested in vitro in the presence of the MMTV, GRE2 or TAT3 promoter co-transfected with GR1 or GR2 is not surprising (Figs 5C, 6A and B). However, such effect of these mutants is not observed with all DNA targets (e.g., $\mathrm{MR}_{\mathrm{DIM}}$ co-transfected with GR2 in the presence of the GRE2 promoter, Fig. 6A), which suggests that for this particular GRE promoter, interaction between the GR and mutated $\mathrm{MR}_{\mathrm{DIM}}$ may either involve other non-receptorregulatory proteins that exert a major effect on GR2 activity or indicate that the DNA layout plays a crucial role. Such an effect of the cellular context in the control of self-synergy of the CRs has already been suggested (Liu et al. 1996). Altogether, these data demonstrate the importance of the integrity of the MR DBD and the GRE context in mediating the repressor activity of the MR on GR-mediated transactivation.

What can we learn from evolution? Of note, repression of one steroid receptor's activity by another steroid receptor has recently been described in another lower vertebrate, amphioxus, a chordate ancestor that diverged from the vertebrates $\sim 500$ MYA, just after a duplication of the ancestral steroid receptor (Delsuc et al. 2006). In amphioxus, a duplication of the ancient ketosteroid receptor gave rise to an estradiol receptor (ER) and a steroid receptor (SR), named after their homology with vertebrate estrogen and steroid receptors. However, the SR retained the ligand-binding abilities and low transcriptional activity (four- to fivefold activation with ligand) of the previous receptor, while the ER does not seem to bind hormones and has no transcriptional activity (Bridgham et al. 2008, Katsu et al. 2010). Thus, the estrogeninsensitive ER functions as a dominant-negative repressor of ligand-activated SR activity through binding to promoter estrogen responsive elements, because mutation of the fourth coordination cysteine in the first zinc finger abolished the ER mediated repression of SR activity in amphioxus (Bridgham et al. 2008, Katsu et al. 2010). Similarly, in rainbow trout, we have shown that MR mediated repression of GR activity seems to be dependent on DNA binding. The duplication of the ancient CR (AncCR) 450 MYA, which gave rise to the GR and the MR, resulted in an MR that retained the ancient hormone binding abilities (cortisol, aldosterone and DOC) and low transcriptional activity, while the ligand specificity (cortisol only) and transcriptional activity of the GR increased (Bridgham et al. 2006, 2009, Ortlund et al. 2007). Thus, in rainbow trout, the MR can act as a ligandactivated repressor of GR activity, but the importance of ligand binding for the repressive function of the MR has still to be clarified.

Heterodimer formation is widely recognized as a key component of transcriptional regulation of cellular mechanisms by the nuclear receptors such as RXR, VDR, PPAR or TR, and this process explains many biological functions of these receptors (Laudet \& Gronemeyer 2002). However, heterodimerization of steroid receptors (GR, MR, progesterone, androgen and estrogen receptors) has been more rarely described, and their functional consequences are still poorly understood. The first clue

Published by Bioscientifica Ltd. 
for understanding the physiological significance of such heterodimerization came from co-localization of the two receptors in the same cells: both receptors have been co-localized in various tissues and cells including the brain, the heart, vascular smooth muscle and leukocytes in mammals (van Steensel et al. 1996, Zennaro et al. 1997, Wickert et al. 1998). A similar situation was also recently observed in trout, where the GR and the MR co-localized in the same cells in the gill, intestine and kidneys (Kiilerich et al. 2011a). Full understanding of the physiological consequences of heterodimerization is still lacking, but such regulation has already been documented in mammals. Thus, study of the regulation of the human $\mathrm{Na}$ /K-ATPase beta1 subunit promoter in CV1 cells has shown that MR interaction with the GR on the promoter effectively down-regulates transcription, and this inhibition was mediated by the N-terminal domain of the MR (NTD-MR) (Derfoul et al. 1998). More recently, the effect of the NTD-MR on glucocorticoid-induced apoptosis in the glucocorticoid-sensitive pre-B lymphoma cell line was analyzed, and results suggest that the NTD-MR mediates the inhibition of glucocorticoid-regulated gene transcription by glucocorticoids (GC) through heterodimerization with the GR (Planey et al. 2002). In neuronal cells, there is also evidence that heterodimerization of the MR and the GR mediates direct corticosteroid-induced trans-repression of the 5-HT1A receptor promoter (Ou et al. 2001). Finally, in the dentate gyrus of the hippocampus, Hassan et al. (1996) provided evidence that MR activation can protect neurons against acute GR-ligand-mediated apoptosis. Altogether, these results suggest that GR-MR interaction mediates a repertoire of cellular responses to $\mathrm{GC}$ in various tissues. Such regulatory pathways probably exist in the fish brain to regulate behavior or exist in osmoregulatory tissues where both the GR and the MR are involved (Kiilerich et al. 2007, 2011a, b, c, McCormick et al. 2008, Sakamoto et al. 2011, Takahashi \& Sakamoto 2013). The MR mediated repression of GR activity reported in this study certainly adds new possibilities to a search for a physiologically relevant function of the MR in fish and requires further studies.

\section{Supplementary data}

This is linked to the online version of the paper at $\mathrm{http}: / / \mathrm{dx}$.doi.org/10.1530/ JME-15-0002.

\section{Declaration of interest}

The authors declare that there is no conflict of interest that could be perceived as prejudicing the impartiality of the research reported.

\section{Funding}

P K was supported by a postdoctoral grant from the Danish National Research Council (09-065881).

\section{Acknowledgements}

We are grateful to Marc Pallardy for the gift of the pGL3-GRE2-Luci construct, to Armin Sturm and Nic Bury for the gift of pEGFP-rtRG1 and pEGFP-rtGR2 plasmids and Michel Pons for the gift of pTAT3-tkLuc construct. We also thank Marie-Edith Oblin for her continuous support and helpful comments during the course of this project.

\section{References}

Adams M, Meijer OC, Wang J, Bhargava A \& Pearce D 2003 Homodimerization of the glucocorticoid receptor is not essential for response element binding: activation of the phenylethanolamine $\mathrm{N}$-methyltransferase gene by dimerization-defective mutant. Molecular Endocrinology 17 2583-2592. (doi:10.1210/me.2002-0305)

Becker H, Sturm A, Bron JE, Schirmer K \& Bury NR 2008 The A/B domain of the teleost glucocorticoid receptors influences partial nuclear localization in the absence of hormone. Endocrinology 149 4567-4576. (doi:10.1210/en.2007-1683)

Bradbury MJ, Akana SF \& Dallman MF 1994 Roles of type I and II corticosteroid receptors in regulation of basal activity in the hypothalamo-pituitary-adrenal axis during the diurnal trough and the peak: evidence for a nonadditive effect of combined receptor occupation. Endocrinology 134 1286-1296. (doi:10.1210/en.134.3.1286)

Bridgham JT, Carroll SM \& Thornton JW 2006 Evolution of hormonereceptor complexity by molecular exploitation. Science 312 97-101. (doi:10.1126/science.1123348)

Bridgham JT, Brown JE, Rodríguez-Marí A, Catchen JM \& Thornton JW 2008 Evolution of a new function by degenerative mutation in cephalochordate steroid receptors. PLoS Genetics 4 e1000191. (doi:10.1371/journal.pgen.1000191)

Bridgham JT, Ortlund EA \& Thornton JW 2009 An epistatic ratchet constrains the direction of glucocorticoid receptor evolution. Nature 461 515-519. (doi:10.1038/nature08249)

Bury NR \& Sturm A 2007 Evolution of the corticosteroid receptor signalling pathway in fish. General and Comparative Endocrinology 153 47-56. (doi:10.1016/j.ygcen.2007.03.009)

Bury NR, Sturm A, Le Rouzic P, Lethimonier C, Ducouret B, Guiguen Y, Robinson-Rechavi M, Laudet V, Rafestin-Oblin ME \& Prunet P 2003 Evidence for two distinct functional glucocorticoid receptors in teleost fish. Journal of Molecular Endocrinology 31 141-156. (doi:10.1677/jme.0. 0310141)

Chen Sy, Wang J, Yu Gq, Liu W \& Pearce D 1997 Androgen and glucocorticoid receptor heterodimer formation. A possible mechanism for mutual inhibition of transcriptional activity. Journal of Biological Chemistry 272 14087-14092. (doi:10.1074/jbc.272.22.14087)

Dahlman-Wright K, Wright A, Gustafsson JA \& Carlstedt-Duke J 1991 Interaction of the glucocorticoid receptor DNA-binding domain with DNA as a dimer is mediated by a short segment of five amino acids. Journal of Biological Chemistry 266 3107-3112.

Delsuc F, Brinkmann H, Chourrout D \& Philippe H 2006 Tunicates and not cephalochordates are the closest living relatives of vertebrates. Nature 439 965-968. (doi:10.1038/nature04336)

Derfoul A, Robertson NM, Lingrel JB, Hall DJ \& Litwack G 1998 Regulation of the human $\mathrm{Na} / \mathrm{K}-\mathrm{ATPa} e \mathrm{\beta} 1$ gene promoter by mineralocorticoid and glucocorticoid receptors. Journal of Biological Chemistry 273 20702-20711. (doi:10.1074/jbc.273.33.20702)

Ducouret B, Tujague M, Ashraf J, Mouchel N, Servel N, Valotaire Y \& Thompson EB 1995 Cloning of a teleost fish glucocorticoid receptor

Published by Bioscientifica Ltd. 
shows that it contains a deoxyribonucleic acid-binding domain different from that of mammals. Endocrinology 136 3774-3783. (doi:10.1210/en.136.9.3774)

Gomez-Sanchez EP, Venkataraman MT, Thwaites D \& Fort C 1990 ICV infusion of corticosterone antagonizes ICV-aldosterone hypertension. American Journal of Physiology. Endocrinology and Metabolism 258 E649-E653.

Green S, Kumar V, Theulaz I, Wahli W \& Chambon P 1988 The N-terminal DNA-binding 'zinc finger' of the oestrogen and glucocorticoid receptors determines target gene specificity. EMBO Journal $\mathbf{7}$ 3037-3044

Greenwood AK, Butler PC, White RB, DeMarco U, Pearce D \& Fernald RD 2003 Multiple corticosteroid receptors in a teleost fish: distinct sequences, expression patterns, and transcriptional activities. Endocrinology 144 4226-4236. (doi:10.1210/en.2003-0566)

Ham J, Thomson A, Needham M, Webb P \& Parker M 1988 Characterization of response elements for androgens, glucocorticoids and progestins in mouse mammary tumour virus. Nucleic Acids Research 16 5263-5276. (doi:10.1093/nar/16.12.5263)

Hassan AH, von Rosenstiel P, Patchev VK, Holsboer F \& Almeida OF 1996 Exacerbation of apoptosis in the dentate gyrus of the aged rat by dexamethasone and the protective role of corticosterone. Experimental Neurology 140 43-52. (doi:10.1006/exnr.1996.0113)

Jiang JQ, Young G, Kobayashi T \& Nagahama Y 1998 Eel (Anguilla japonica) testis $11 \beta$-hydroxylase gene is expressed in interrenal tissue and its product lacks aldosterone synthesizing activity. Molecular and Cellular Endocrinology 146 207-211. (doi:10.1016/S03037207(98)00147-6)

Katsu Y, Kubokawa K, Urushitani H \& Iguchi T 2010 Estrogen-dependent transactivation of amphioxus steroid hormone receptor via both estrogen and androgen response elements. Endocrinology 151 639-648. (doi:10.1210/en.2009-0766)

Kiilerich P \& Prunet P 2011 Corticosteroids. In Encyclopedia of Fish Physiology: From Genome to Environment. Volume 2. Gas Exchange, Internal Homeostatis, and Food Uptake, 1474-1482. London, UK: Academic Press.

Kiilerich P, Kristiansen K \& Madsen SS 2007 Cortisol regulation of ion transporter mRNA in Atlantic salmon gill and the effect of salinity on the signaling pathway. Journal of Endocrinology 194 417-427. (doi:10.1677/JOE-07-0185)

Kiilerich P, Milla S, Sturm A, Valotaire C, Chevolleau S, Giton F, Terrien X, Fiet J, Fostier A, Debrauwer L et al. 2011a Implication of the mineralocorticoid axis in rainbow trout osmoregulation during salinity acclimation. Journal of Endocrinology 209 221-235. (doi:10.1530/ JOE-10-0371)

Kiilerich P, Pedersen SH, Kristiansen K \& Madsen SS $2011 b$ Corticosteroid regulation of $\mathrm{Na}(+), \mathrm{K}(+)$-ATPase $\alpha 1$-isoform expression in Atlantic salmon gill during smolt development. General and Comparative Endocrinology 170 283-289. (doi:10.1016/j.ygcen.2010.02.014)

Kiilerich P, Tipsmark CK, Borski RJ \& Madsen SS 2011c Differential effects of cortisol and 11-deoxycorticosterone on ion transport protein mRNA levels in gills of two euryhaline teleosts. Mozambique tilapia (Oreochromis mossambicus) and striped bass (Morone saxatilis). Journal of Endocrinology 209 115-126. (doi:10.1530/JOE-10-0326)

Kim MA, Kim DS \& Sohn YC 2011 Characterization of two functional glucocorticoid receptors in the marine medaka Oryzias dancena. General and Comparative Endocrinology 171 341-349. (doi:10.1016/ j.ygcen.2011.02.015)

Laudet V \& Gronemeyer H 2001 The nuclear receptor factsbook. Strasbourg, France: Academic Press.

Li Y, Sturm A, Cunningham P \& Bury NR 2012 Evidence for a divergence in function between two glucocorticoid receptors from a basal teleost. BMC Evolutionary Biology 12 137. (doi:10.1186/1471-2148-12-137)

Liu W, Wang J, Sauter NK \& Pearce D 1995 Steroid receptor heterodimerization demonstrated in vitro and in vivo. PNAS 92 12480-12484. (doi:10.1073/pnas.92.26.12480)
Liu W, Wang J, Yu G \& Pearce D 1996 Steroid receptor transcriptional synergy is potentiated by disruption of the DNA-binding domain dimer interface. Molecular Endocrinology 10 1399-1406. (doi:10.1210/me.10. 11.1399)

McCormick SD, Regish A, O’Dea MF \& Shrimpton JM 2008 Are we missing a mineralocorticoid in teleost fish? Effects of cortisol, deoxycorticosterone and aldosterone on osmoregulation, gill $\mathrm{Na}+, \mathrm{K}+$-ATPase activity and isoform mRNA levels in Atlantic salmon General and Comparative Endocrinology 157 35-40. (doi:10.1016/j.ygcen.2008.03.024)

Meijsing SH, Pufall MA, So AY, Bates DL, Chen L \& Yamamoto KR 2009 DNA binding site sequence directs glucocorticoid receptor structure and activity. Science 324 407-410. (doi:10.1126/science.1164265)

Milla S, Terrien X, Sturm A, Ibrahim F, Giton F, Fiet J, Prunet P \& Le Gac F 2008 Plasma 11-deoxycorticosterone (DOC) and mineralocorticoid receptor testicular expression during rainbow trout Oncorhynchus mykiss spermiation: implication with $17 \alpha, 20 \beta$-dihydroxyprogesterone on the milt fluidity? Reproductive Biology and Endocrinology 619. (doi:10.1186/1477-7827-6-19)

Nishi M, Ogawa H, Ito T, Matsuda KI \& Kawata M 2001 Dynamic changes in subcellular localization of mineralocorticoid receptor in living cells: in comparison with glucocorticoid receptor using dual-color labeling with green fluorescent protein spectral variants. Molecular Endocrinology 15 1077-1092. (doi:10.1210/mend.15.7.0659)

Nishi M, Tanaka M, Matsuda K, Sunaguchi M \& Kawata M 2004 Visualization of glucocorticoid receptor and mineralocorticoid receptor interactions in living cells with GFP-based fluorescence resonance energy transfer. Journal of Neuroscience 24 4918-4927. (doi:10.1523/ JNEUROSCI.5495-03.2004)

Ortlund EA, Bridgham JT, Redinbo MR \& Thornton JW 2007 Crystal structure of an ancient protein: evolution by conformational epistasis. Science 317 1544-1548. (doi:10.1126/science.1142819)

Ou XM, Storring JM, Kushwaha N \& Albert PR 2001 Heterodimerization of mineralocorticoid and glucocorticoid receptors at a novel negative response element of the 5-HT1A receptor gene. Journal of Biological Chemistry 276 14299-14307.

Payvar F, DeFranco D, Firestone GL, Edgar B, Wrange O, Okret S, Gustafsson JA \& Yamamoto KR 1983 Sequence-specific binding of glucocorticoid receptor to MTV DNA at sites within and upstream of the transcribed region. Cell 35 381-392. (doi:10.1016/00928674(83)90171-X)

Planey SL, Derfoul A, Steplewski A, Robertson NM \& Litwack G 2002 Inhibition of glucocorticoid-induced apoptosis in 697 pre-B lymphocytes by the mineralocorticoid receptor N-terminal domain. Journal of Biological Chemistry 277 42188-42196. (doi:10.1074/jbc.M205085200)

Rupprecht R, Arriza JL, Spengler D, Reul JM, Evans RM, Holsboer F \& Damm K 1993 Transactivation and synergistic properties of the mineralocorticoid receptor: relationship to the glucocorticoid receptor. European Journal of Pharmacology 247 145-154. (doi:10.1016/09224106(93)90072-H)

Rusconi S \& Yamamoto KR 1987 Functional dissection of the hormone and DNA binding activities of the glucocorticoid receptor. EMBO Journal 6 1309-1315.

Sakamoto T, Mori C, Minami S, Takahashi H, Abe T, Ojima D, Ogoshi M \& Sakamoto H 2011 Corticosteroids stimulate the amphibious behavior in mudskipper: potential role of mineralocorticoid receptors in teleost fish. Physiology \& Behavior 104 923-928. (doi:10.1016/j.physbeh.2011. 06.002)

Savory JG, Préfontaine GG, Lamprecht C, Liao M, Walther RF, Lefebvre YA \& Haché RJ 2001 Glucocorticoid receptor homodimers and glucocorticoid-mineralocorticoid receptor heterodimers form in the cytoplasm through alternative dimerization interfaces. Molecular and Cellular Biology 21 781-793. (doi:10.1128/MCB.21.3.781-793.2001)

Schena M, Freedman LP \& Yamamoto KR 1989 Mutations in the glucocorticoid receptor zinc finger region that distinguish interdigitated DNA binding and transcriptional enhancement activities. Genes and Development 3 1590-1601. (doi:10.1101/gad.3.10.1590) 
van Steensel B, van Binnendijk EP, Hornsby CD, van der Voort HT, Krozowski ZS, de Kloet ER \& van Driel R 1996 Partial colocalization of glucocorticoid and mineralocorticoid receptors in discrete compartments in nuclei of rat hippocampus neurons. Journal of Cell Science $\mathbf{1 0 9}$ 787-792.

Stolte EH, de Mazon AF, Leon-Koosterziel KM, Jesiak M, Bury NR, Sturm A, Savelkoul HF, van Kemenade BM \& Flik G 2008a Corticosteroid receptors involved in stress regulation in common carp, Cyprinus carpio. Journal of Endocrinology 198 403-417. (doi:10.1677/ JOE-08-0100)

Stolte EH, Nabuurs SB, Bury NR, Sturm A, Flik G, Savelkoul HF \& Lidy Verburg-van Kemenade BM $2008 b$ Stress and innate immunity in carp: corticosteroid receptors and pro-inflammatory cytokines. Molecular Immunology 46 70-79. (doi:10.1016/j.molimm.2008.07.022)

Sturm A, Bury N, Dengreville L, Fagart J, Flouriot G, Rafestin-Oblin ME \& Prunet P 2005 11-deoxycorticosterone is a potent agonist of the rainbow trout (Oncorhynchus mykiss) mineralocorticoid receptor. Endocrinology 146 47-55. (doi:10.1210/en.2004-0128)

Takahashi H \& Sakamoto T 2013 The role of 'mineralocorticoids' in teleost fish: relative importance of glucocorticoid signaling in the osmoregulation and 'central' actions of mineralocorticoid receptor. General and Comparative Endocrinology 181 223-228. (doi:10.1016/j.ygcen. 2012.11.016)

Trapp T, Rupprecht R, Castrén M, Reul JM \& Holsboer F 1994 Heterodimerization between mineralocorticoid and glucocorticoid receptor: a new principle of glucocorticoid action in the CNS. Neuron 13 1457-1462. (doi:10.1016/0896-6273(94)90431-6)
Trayer V, Hwang PP, Prunet P \& Thermes V 2013 Assessment of the role of cortisol and corticosteroid receptors in epidermal ionocyte development in the medaka (Oryzias latipes) embryos. General and Comparative Endocrinology 194 152-161. (doi:10.1016/j.ygcen. 2013.09.011)

Tsai SY, Carlstedt DG, Weigel NL, Dallman K, Gustafsson J, Tsai MJ \& O'Malley BW 1988 Molecular interactions of steroid hormone receptor with its enhancer element: evidence for receptor dimer formation. Cell 55 361-369. (doi:10.1016/00928674(88)90059-1)

Tujague M, Saligaut D, Teitsma C, Kah O, Valotaire Y \& Ducouret B 1998 Rainbow trout glucocorticoid receptor overexpression in Escherichia coli: production of antibodies for western blotting and immunohistochemistry. General and Comparative Endocrinology 110 201-211. (doi:10.1006/gcen.1998.7066)

Vinson GP 2011 The mislabelling of deoxycorticosterone: making sense of corticosteroid structure and function. Journal of Endocrinology 211 3-16. (doi:10.1530/JOE-11-0178)

Wickert L, Watzka M, Bolkenius U, Bidlingmaier F \& Ludwig M 1998 Mineralocorticoid receptor splice variants in different human tissues. European Journal of Endocrinology/European Federation of Endocrine Societies 138 702-704. (doi:10.1530/eje.0.1380702)

Zennaro MC, Farman N, Bonvalet JP \& Lombes M 1997 Tissue-specific expression of $\alpha$ and $\beta$ messenger ribonucleic acid isoforms of the human mineralocorticoid receptor in normal and pathological states. Journal of Clinical Endocrinology and Metabolism 82 1345-1352. (doi:10.1210/jc.82.5.1345)

Received in final form 18 May 2015

Accepted 22 June 2015

Accepted Preprint published online 24 June 2015
(C) 2015 Society for Endocrinology Printed in Great Britain 